Article

\title{
New Soil, Old Plants, and Ubiquitous Microbes: Evaluating the Potential of Incipient Basaltic Soil to Support Native Plant Growth and Influence Belowground Soil Microbial Community Composition
}

\author{
Aditi Sengupta ${ }^{1, *,+}{ }^{\text {, Priyanka Kushwaha }}{ }^{2}$, Antonia Jim ${ }^{3}$, Peter A. Troch ${ }^{1,4}$ and Raina Maier ${ }^{2}$ \\ 1 Biosphere 2, University of Arizona, Tucson, AZ 85721, USA; patroch@hwr.arizona.edu \\ 2 Department of Environmental Science, University of Arizona, Tucson, AZ 85721, USA; \\ pkushwaha@email.arizona.edu (P.K.); rmaier@ag.arizona.edu (R.M.) \\ 3 Department of Environment and Sustainability, Fort Lewis College, Durango, CO 81301, USA; \\ aljim1@fortlewis.edu \\ 4 Department of Hydrology and Atmospheric Sciences, University of Arizona, Tucson, AZ 85721, USA \\ * Correspondence: aditi.sengupta@pnnl.gov \\ + Author's current address: Earth and Biological Sciences Directorate, Pacific Northwest National Laboratory, \\ 902 Battelle Boulevard, MSIN J4-18, Richland, Washington, DC 99352, USA.
}

Received: 22 March 2020; Accepted: 18 May 2020; Published: 21 May 2020

\begin{abstract}
The plant-microbe-soil nexus is critical in maintaining biogeochemical balance of the biosphere. However, soil loss and land degradation are occurring at alarmingly high rates, with soil loss exceeding soil formation rates. This necessitates evaluating marginal soils for their capacity to support and sustain plant growth. In a greenhouse study, we evaluated the capacity of marginal incipient basaltic parent material to support native plant growth and the associated variation in soil microbial community dynamics. Three plant species, native to the Southwestern Arizona-Sonora region, were tested with three soil treatments, including basaltic parent material, parent material amended with $20 \%$ compost, and potting soil. The parent material with and without compost supported 15\%, 40\%, and 70\% germination of Common Bean (Phaseolus vulgaris L. 'Tarahumara Norteño'), Mesquite (Prosopis pubescens Benth), and Panic Grass (Panicum Sonorum Beal), respectively, though germination was lower than in the potting soil. Plant growth was also sustained over the 30 day period, with plants in parent material (with and without amendment) reaching $50 \%$ height compared to those in the potting soil. A $16 \mathrm{~S}$ rRNA gene amplicon sequencing approach showed Proteobacteria to be the most abundant phyla in both parent material and potting soil, followed by Actinobacteria. The potting soil showed Gammaproteobacteria (19.6\%) to be the second most abundant class, but its abundance was reduced in the soil + plants treatment (5.6\%-9.6\%). Within the basalt soil type, Alphaproteobacteria (42.7\%) and Actinobacteria (16.3\%) had a higher abundance in the evaluated bean plant species. Microbial community composition had strong correlations with soil characteristics, but not plant attributes within a given soil material. Predictive functional potential capacity of the communities revealed chemoheterotrophy as the most abundant metabolism within the parent material, while photoheterotrophy and anoxygenic photoautotrophy were prevalent in the potting soil. These results show that marginal incipient basaltic soil, both with and without compost amendments, can support native plant species growth, and non-linear associations may exist between plant-marginal soil-microbial interactions.
\end{abstract}

Keywords: marginal soil; land degradation; endemic plant species; soil microbes 


\section{Introduction}

Soils provide a wide range of ecosystem services and are central to sustaining life in the biosphere. These include supporting plant growth and sustenance, ensuring food security, and modulating biogeochemical cycles [1]. Additionally, soils hold anthropological significance, as civilizations have developed and flourished around their ability to harness soils' power to grow crops. However, global soil loss is occurring at unprecedented rates with depletion rates twenty times faster than formation in the United States alone [2,3]. Soil loss and eventual land degradation are exacerbated by anthropogenic activities including urbanization, population growth, machine-intensive agricultural practices, conversion of forest land to agricultural land, and land-use practices such as mining. Degraded land quality, in turn, negatively impacts food production, livelihoods, and ecosystem services [4].

The process of rock to soil formation and, therefore, landscape development occurs over hundreds of years, with a predicted 500-1000 years needed to form $2.5 \mathrm{~cm}$ of top soil [1]. This imbalance between rates of soil formation and depletion is unsustainable. Soil conservation therefore stands out as a necessity if humans are to secure food, fiber, economy, and health. The Land Degradation Neutrality (LDN) Program adopted by the United Nations Convention to Combat Desertification (UNCCD) recognized that land conservation requires restoring degraded land and soil to achieve a "degradation-neutral world" [5]. A key concept of the neutrality framework is to improve the productive potential of land/soil that is already degraded [6], with calls for restoration and rehabilitation mechanisms. We propose exploring the capacity of marginal soils as one approach to revegetate marginal soils and increase ecosystem service of degraded lands both in terms of regulating services (e.g., climate regulation, hydrological regulation, regulation of soil erosion) provisioning services (e.g., crops, livestock, fuel, fiber), and cultural services (local heritage, recreation, tourism, education) [7].

Seed germination is a critical step in plant establishment and needs detailed evaluation in marginal soils with constrained physicochemical conditions. Previous studies of contaminated mine tailings have shown successful germination of native Atriplex lentiformis and Bouteloua dactyloides seeds within the first week in mine tailings amended with compost [8-10]. Previous studies have also demonstrated use of plant-growth-promoting bacteria to establish native plants in Klondyke mine tailings in Arizona [11] and aid phytoremediation of contaminated soils [12]. Another study showed a seed mixture of 15 native seeds sown on degraded soils on the Falkland island, of which three species, Elymus magellanicus, Poa flabellate, and Poa alopecarus, successfully germinated during a revegetation trial [13]. Therefore, plant-specific establishment rates may vary, and, along with plant diversity, tissue chemistry, and root traits [14], will impact soil characteristics and plant-soil-microbe interactions in marginal soils. From a land-sustainability standpoint, the concept of using native seeds specifically sourced from the areas close to the parent material is environmentally sustainable. For example, native seed use preserves the local biodiversity and ensures that a diverse plant gene pool is present, thereby reducing disease vulnerability [15]. Moreover, using locally sourced seeds can reduce environmental and economic costs incurred in producing and transporting seeds from distant locations, especially for subsistence farmers who cannot rely on industry-scale operations [16,17].

Native plants have also been reported to act as ecological resource islands by improving soil chemical and microbial properties of adjacent rhizosphere soil [18] and can therefore improve local land productivity. Land degradation reduces soil microbial biomass and microbial activity [19], with reports of significant decrease in beneficial microorganisms and increase in pathogenic ones in degraded soils [20]. Another study [21] found higher bacterial richness and diversity in restored soils and soils under native vegetation in comparison to degraded soils. As invisible engineers of terrestrial ecosystems, soil microorganisms contribute to soil structure, are involved in biogeochemical cycling of nutrients [22], decompose organic matter, impact plant diversity and productivity, and play a critical role in soil fertility [23].

The aboveground-belowground links between plant and microbes are especially crucial in marginal systems' characteristic of nutrient-poor soils and inferior soil structure. Soil biota is one of 
the five soil forming factors proposed by Hans Jenny [24]. In marginal soils lacking higher life forms, microbes are therefore the first biotic component to contribute to soil stabilization and structure. Hence, evaluating microbial community establishment and response in marginal soils is critical. Empirical knowledge of these linkages can then be potentially applied to enhance marginal soils' capacity to support plant growth, e.g., by developing microbe-mediated amendment technologies suited to low-productivity landscapes.

Marginal soils can include incipient soils, soils affected by mining processes and fire, over-used agricultural lands, urban vacant plots, and primary succession ecosystems [25,26]. Soils in these landscapes have poor quality, have a persistent lack of plant growth, and are characterized by a lack of stable soil aggregates, organic carbon forms, and essential plant nutrients [26,27]. Restoring the productive capacity of marginal land is critical to the mission of the LDN Framework of the UNCDD taskforce [5]. Our study uses basaltic material as a marginal soil medium and is novel in its concept, since a literature survey revealed that such material, despite being rich in nutrients, has not been evaluated for plant growth purposes. Marginal soil productivity and efficacy in supporting plant growth are therefore a potential way of compensating for global soil loss and supporting sustainable land management.

Landscape evolution of marginal incipient soils includes spatio-temporal interactions spanning coupled hydrobiogeochemical processes. Field studies fall short of capturing these critical process responses during the initial stages of development, including soil stabilization and plant establishment [28]. In this study, we evaluated the capacity of basaltic soil material to support native plant growth and the associated variation in soil microbial community dynamics following a month-long greenhouse experiment. The incipient soil is basaltic crushed tephra sourced from Merriam crater in northern Arizona, and is being extensively studied at the Landscape Evolution Observatory (LEO) housed at Biosphere 2 in University of Arizona to understand coupled hydrobiogeochemical processes of landscape evolution $[28,29]$. The timeframe of the greenhouse study was selected to test for seeds that could germinate and plants that could grow within a month, keeping in mind the larger scope of this research at the LEO hillslopes, which see two-three month-long rainfall episodes each year and are in the process of being vegetated. The seeds selected for this study were native to the Arizona-Sonora region, reflected those of plants with different rooting patterns, could withstand high water availability as expected to be present in the LEO hillslopes, and could withstand high Arizona summer temperatures. This lithogenic basalt parent material is oligotrophic, with low carbon $\left(9.33 \times 10^{-5} \mu \mathrm{g} / \mathrm{mg}\right)$, nitrogen $\left(4.33 \times 10^{-6} \mu \mathrm{g} / \mathrm{mg}\right)$ [30], and phosphorus content $(0.003 \mu \mathrm{g} / \mathrm{mg})$ [31], but has been shown to harbor microbial life [32]. The soil texture of LEO basalt material is loamy sandy (\% sand: $84.6, \%$ silt: 12.2 , and \% clay: 3.2 ). The soil was contrasted with a potting soil treatment, which served as a positive control, as well as a basalt soil amended with compost treatment, which served as a comparative mid-point between the marginal basalt soil and the nutrient-rich potting soil.

The objectives of this study were to (i) evaluate germination capacity and plant growth capacity of the basaltic parent material for three seed types, (ii) compare growth of the different species in the parent material with and without compost amendment as compared to potting soil, and (iii) assess soil microbial community composition and functional potential between treatments. The seeds used in this study were sourced from the seed banks of Native Seed Search [33] and were native to the Arizona/Sonora region of Arizona. We hypothesized that for each plant species, the highest germination, plant height, and biomass will be observed in the potting soil, followed by compost-amended basalt soil, with the lowest plant attributes observed in the basalt soil. These differences would also be visible as distinct soil characteristics at the end of the experiment. Additionally, we hypothesized that the soil microbial community for each plant species would be significantly different between the soil treatments, resulting in different predictive functional profiles of the microbial communities. 


\section{Materials and Methods}

\subsection{Experimental Design}

A greenhouse pot experiment was conducted with three seed types: Panic Grass (Panicum Sonorum Beal), Mesquite (Prosopis pubescens Benth), and Common Bean (Phaseolus vulgaris L. 'Tarahumara Norteño'), as well as three soil materials: Basaltic parent material from the LEO experiment (LPM), LEO parent material $+20 \% \mathrm{w} / \mathrm{w}$ commercially available compost (LPMC), and commercially available (Miracle Gro ${ }^{\circledR}$ Potting Mix) potting soil (PS). Percent moisture was measured after drying field-moist soils at $105^{\circ} \mathrm{C}$ for $24 \mathrm{hrs}$. The total carbon (TC), organic carbon (TOC), and nitrogen (TN) concentrations (U.S. EPA method 415.3) were measured using a TOC-L Series total organic carbon and nitrogen analyzer, equipped with a TOC-LCSH autosampler (Shimadzu, Kyoto, Japan) [28,34]. The TC, TOC, and $\mathrm{TN}$ concentrations in the compost material were $138 \pm 7 \mu \mathrm{g} \mathrm{g}^{-1}, 120 \pm 5 \mu \mathrm{g} \mathrm{g}^{-1}$, and $3.0 \pm 0.56 \mu \mathrm{g} \mathrm{g}^{-1}$, respectively, while the potting soil recorded $294 \pm \mu \mathrm{g} \mathrm{g}{ }^{-1}, 213 \pm 3.0 \mu \mathrm{g} \mathrm{g}^{-1}$, and $13.34 \pm 1.0 \mu \mathrm{g} \mathrm{g}^{-1}$, respectively. Compost was added to evaluate the effect of natural amendment on LPM's capacity to support plant growth while potting soil served as a positive control. Each seed-type-soil material combination ( $\mathrm{n}=27)$ was set up in randomized triplicate one-gallon plastic pots with $2.1 \mathrm{~kg}$ LPM, $2.1 \mathrm{~kg}(1.68 \mathrm{~kg} \mathrm{LPM}+0.42 \mathrm{~kg}$ compost) LPMC, and $0.6 \mathrm{~kg}$ PS, and ten seeds sown per pot. The drip irrigation system was controlled at three one-minute events a day at 8:30 a.m., 12:00 p.m., and 4:30 p.m., respectively, for seven days a week, totaling $720 \mathrm{~mL} /$ day/pot of tap water and pots monitored for 30 days (24 June-24 July 2017). The lowest and highest temperature range for the 30 days were $19-23^{\circ} \mathrm{C}$ and $31-44^{\circ} \mathrm{C}$, respectively.

The one-month timeframe was chosen for multiple reasons. First, it was primarily driven by the ability to study seeds that have short germination times, eventually leading up to fast-growing plants. This would allow initial responses of plant-soil-microbe interaction in the nascent stages of germination and growth in an incipient soil to be captured. Moreover, to inform the larger scope of the research, seeds were chosen that fit the research motivation at the LEO in Biosphere 2, which sees two-three month-long rainfall episodes in a year and, therefore, needs plants that can germinate within a month and withstand the water exposure at the hillslopes. This also informed our irrigation regime, which was designed to not be water-constrained. This allowed observations to be made with the underlying fact that the only constraints provided to the seeds/plants were the marginal soil characteristics.

The soil treatments were chosen to first evaluate the plant growth capacity of the incipient basalt parent material. Next, a literature review suggested that marginal soils support plant growth when treated with amendments, which motivated us to add a compost-amendment treatment. The decision to go with $20 \%$ compost was arrived at after evaluating literature [8-10]. Potting soil was chosen as a positive control to validate our experimental design and evaluate whether the seeds we were using would indeed germinate and grow in the one-month-long summer experiment. The treatments therefore provided contrasting soil environments, especially beneficial to test the initial plant-soil-microbe interactions and responses in the initial stages of plant growth, and to differing levels of soil fertility $(\mathrm{C}, \mathrm{N})$ and moisture.

\subsection{Seed Information}

Detailed seed information and sowing are provided in a preliminary publication by Jim and Sengupta [35]. Panic grass (Panicum Sonorum) was cultivated in the Arizona and Sonora region four thousand years ago. Prosopis pubescens, or Mesquite, grows in arid and semi-arid environments, such as deserts, woodlands, floodplains, grasslands, and shrublands, and has deep tap roots with leaves adapted to reduce water loss. Tarahumara Norteño bean (also known as the common bean), originated in the Tarahumara area of the Chihuahua region in Mexico and has been widely cultivated by Native American farmers throughout the Southwest $[33,36]$. Common beans are known to grow in semi-tropical regions and host nitrogen-fixing bacteria in their root nodules. The three seed types 
typically grow in arid to semi-arid environments, are heat tolerant, can retain water, and have short germination periods. The grass and bean seeds were sourced from Native Seeds, Tucson, AZ and mesquite seeds were sourced from Desert Nursery, Phoenix, AZ.

The plant species were selected primarily keeping in mind the larger goal of providing robust preliminary data to the research team at the Landscape Evolution Observatory, where the goal is to study the hydrobiogoechemical trajectory of landscape evolution from incipient soil to a vegetated landscape. The criteria were: (i) The plants would germinate fast and grow considerably during the one-month study period, (ii) the plants would represent a range of root systems (for example, Mesquite for tap roots, Panic Grass for shallow fibrous root, and Common Bean for a mix of adventitious and basal root systems), and (iii) the plants would be native to the Arizona-Sonora region primarily so that they could tolerate the heat and would be able to grow on the basaltic hillslopes of the Landscape Evolution Observatory.

\subsection{Plant and Soil Measurements}

Percent germination was calculated after ten days. One plant per pot was marked and monitored continuously, with height measurements taken once every week. At the end of the experiment, the marked plant was harvested for wet and dry aboveground biomass measurement as per protocol outlined in Jim and Sengupta [35]. Bulk density (BD) cores were collected using metallic cores of height $2.9 \mathrm{~cm}$ and diameter $5.3 \mathrm{~cm}$. Bulk soil samples close to the roots were also collected for geochemical and microbiological analyses, stored on ice, and brought back to the lab for processing. Half of the bulk samples were air-dried and sieved for $\mathrm{pH}$, carbon, and nitrogen measurements, while the other half was frozen at $-80^{\circ} \mathrm{C}$.

\subsection{Soil Microbial Community Analysis}

Soil microbial DNA from the frozen soils was extracted using a modified extraction protocol $[8,32]$ of the FastDNA ${ }^{\mathrm{TM}}$ SPIN Kit for Soil from MP Biomedicals with an additional $5.5 \mathrm{M}$ guanidine thiocyanate wash step to remove humic acids, and was sent for sequencing to the University of Arizona Genetics Core (UAGC; Tucson, AZ, USA). Sequence data were analyzed as per protocols highlighted in Sengupta et al. 2019 [32]. Briefly, paired-end sequencing $(2 \times 150 \mathrm{bp})$ was performed on the bacterial and archaeal 16S rRNA gene V4 (515F-806R primers) hypervariable region using the Illumina MiSeq platform (Illumina, CA, USA) [37]. All of the sequencing procedures, including the construction of the Illumina sequencing library, were performed using the protocol previously published [38] with modifications [39]. Illumina MiSeq v2 (300 bp) chemistry was used for sequencing and was performed on the Illumina MiSeq (SN M02149 with the MiSeq Control Software v 2.5.0.5) at the UAGC following their standard protocols. The UAGC provided standard Illumina quality control, base-calling, demultiplexing, adaptor removal, and conversion to FastQ format. Raw sequence data were submitted to NCBI's Sequence Read Archive SUB4001574, ProjectID PRJNA464263.

Paired-end sequence merging, barcode removal, quality filtering, singleton-sequence removal, chimera checking and removal, and open-reference Operational Taxonomic Unit (OTU) picking were conducted using default parameters unless otherwise specified in QIIME v 1.9.1 [37]. A minimum overlap of 20 bases was specified for joining the paired reads to give an average sequence length of 253 base pairs. A summary of the sequences, post-merging and quality filtering, was performed using mothur (v 1.25) [39], OTU picking was done using UCLUST [40], and sequence alignment was performed with PyNAST [41]. Clustering was done with Greengenes database at $97 \%$ sequence similarity [42], chimera were removed with Chimera Slayer [43], taxonomy was assigned with RDP Classifier [44], tree building was completed with FastTree [45], and comparative diversity calculations were done with UniFrac [46]. OTUs that were observed only once after chimera filtering were removed. All data files generated from the QIIME workflow were imported into the $R$ environment program [47] for alpha and beta diversity estimation and visualization using Phyloseq [48]. 


\subsection{Functional Annotation of Sequence Data}

The 16S rRNA amplicon gene sequences were used to infer metabolic traits from phylogeny using the tool Functional Annotation of Prokaryotic Taxa (FAPROTAX) [49]. FAPROTAX facilitates interpretation of microbial functional profiles from $16 \mathrm{~S}$ rRNA bacterial and archaeal sequence data based on available literature of cultured representatives. Briefly, an OTU is associated with a particular metabolic function if all cultured representatives of that OTU are reported to exhibit that function. For example, if all cultured representatives of a genus have been identified as nitrifiers, FAPROTAX assumes all uncultured members to be nitrifiers as well. This approach was well suited to our study given the complexity of soil environments, and a large portion of soil microbes remain uncultured.

\subsection{Data Analyses}

Percent germination, plant height, aboveground wet and dry biomass, $\mathrm{pH}$, bulk density, carbon (total, organic, and inorganic), total nitrogen, and moisture content were statistically analyzed using JMP ${ }^{\circledR}$ 13.0. Significant differences of mean were determined by one-way analysis of variance (ANOVA) $(P<0.05)$, followed by pairwise comparisons of the means of each soil material/plant group using Tukey's Honest Significance Difference test with significance levels at $P<0.05$. Sequences were evaluated for alpha (Richness and Shannon's Index), and beta diversity metrics (Bray-Curtis) were analyzed with Principal Coordinate analysis (PCoA). To visualize predicted functional differences between the soil types, a heatmap was generated using the gplots [50] package in R. Additionally, a hierarchical cluster was generated using the average linkage method. To determine the dissimilarity in the microbial community structures and the soil physicochemical properties together with plant measurements, a non-parametric multivariate analysis of variance (PERMANOVA) was performed based on the Bray-Curtis dissimilarity. Additionally, Mantel tests were performed to determine correlations between the soil microbial communities and the environmental factors. PERMANOVA and Mantel's test analyses were carried out in R (v.3.5) using the package vegan [51] and ade4 [52], respectively. For PERMANOVA analyses, there was no replication. For LEO soil material and potting soil, there were three and four samples, respectively. To perform the PERMANOVA as well as Mantel's test, $\mathrm{n}=999$ iterations were used. ANOVA analysis was conducted using relative abundance of OTUs classified as specific functional guilds using FAPROTAX. The F-value was used to evaluate the ratio of mean square values of the samples separated into the two soil types.

\section{Results and Discussion}

\subsection{Germination, Plant Height and Aboveground Biomass}

Plant characteristics including germination, plant height, and aboveground biomass were monitored for 30 days in a greenhouse (Figure 1). The results are presented in Jim and Sengupta [35] with additional statistical testing between all treatments and interpretation discussed here.

Briefly, all three soil treatments supported germination, with the maximum percent germination observed in the potting soil and the overall highest germination of grasses across treatments. Malfunctioning irrigation drips discovered towards the end of the experiment in one replicate pot each of parent material and parent material amended with compost may explain the low germination rates for the bean plants in basalt soil and basalt amended with compost. 


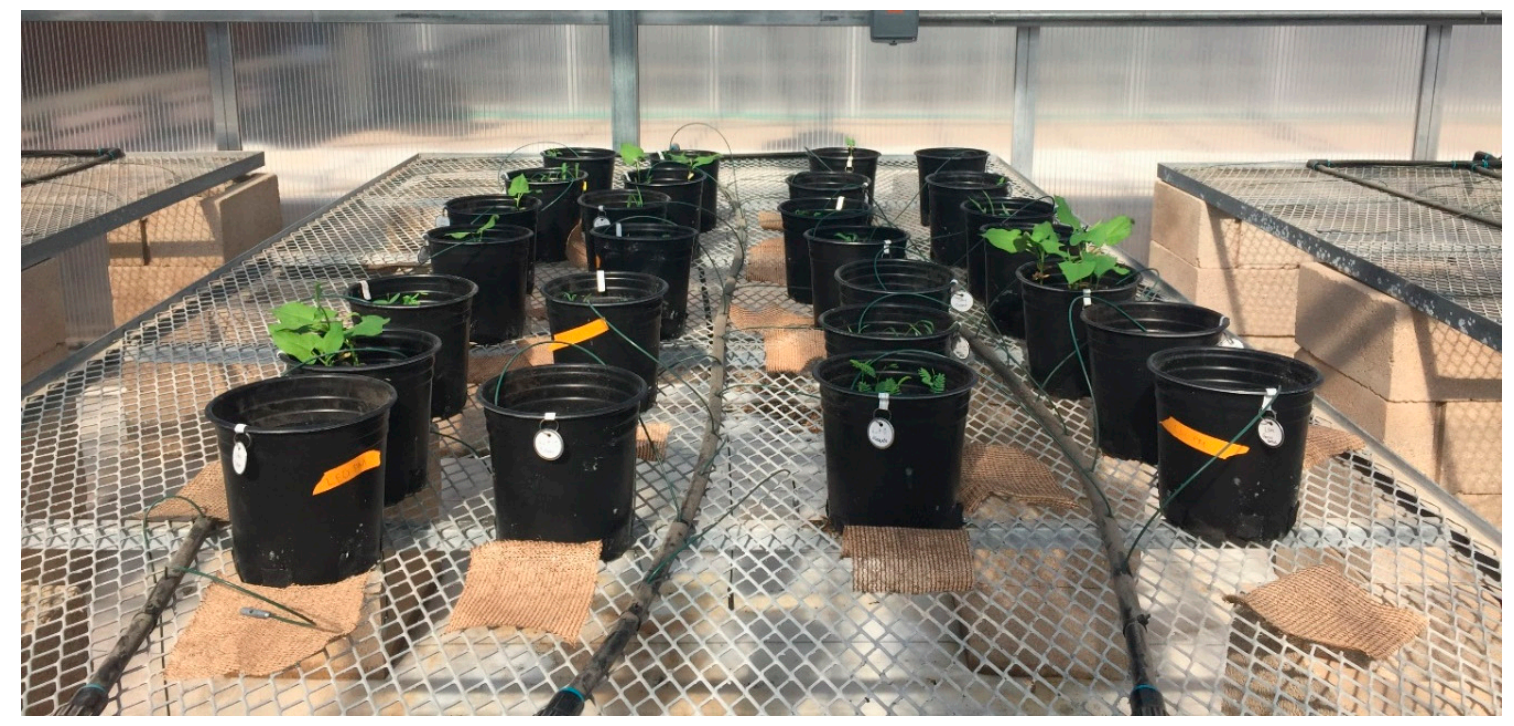

Figure 1. Greenhouse experimental set-up on Day 10.

As noted in Jim and Sengupta [35], significantly higher plant growth was observed in the potting soil as compared to basalt soil and basalt soil amended with compost. The bean and grass plants grew twice the height (averages of 40 and $54 \mathrm{~cm}$, respectively) in the potting soil as compared to basalt with and without amendments, while the slowest growing plant was bean in parent material. Significant aboveground biomass accumulation was observed for bean and grass plants in the potting soil as compared to the parent material with and without amendment, with the lowest biomass accumulation in mesquite across soil treatments and no significant differences between the soil treatments [35]. However, it is likely that a period of 30 days may not be sufficient for compost benefits to be visible owing to the slow release of nutrients [53]. Therefore, a longer growth period may be necessary for compost-amendment benefits to be observable.

This provides a positive indication of LEO basalt material's ability to support germination and promote plant growth (Figure 2). Additionally, these results show that locally sourced native seeds can prove to be an effective strategy in vegetating incipient soils that are localized around the native plant source. Moreover, the rapid germination of seeds in the LEO basaltic material can stabilize the soil and facilitate ecosystem succession, as highlighted by Smith et al. [13], who reported rapid revegetation of degraded land by incorporating native plant species.
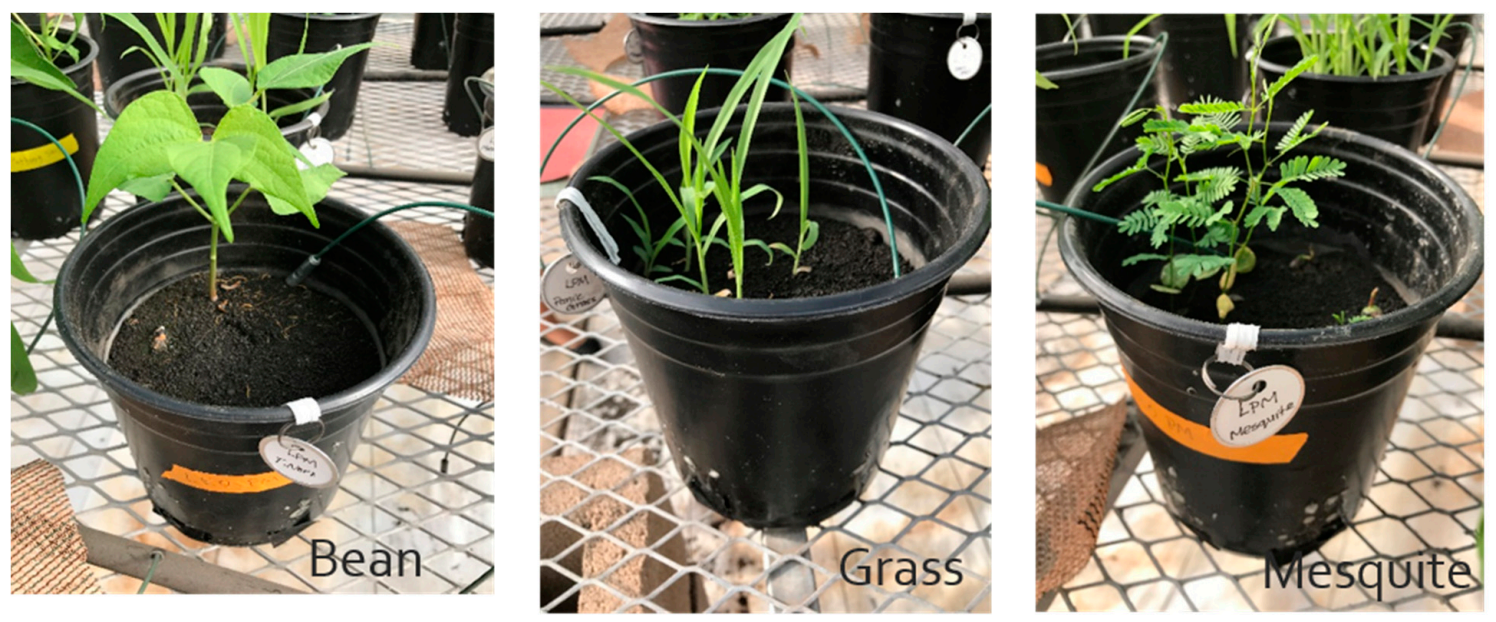

Figure 2. Growth observed in basalt parent material for all three seed types. 


\subsection{Physico-Chemical Properties of the Studied Soil Materials}

Physico-chemical data of the treatments as well as irrigation water, parent material, and potting soil are presented in Supplementary Table S1. Soil pH differed between treatments, with pH significantly higher in the parent material and parent material amended with compost as compared to potting soil. A decrease in $\mathrm{pH}$ was observed in the basaltic parent material $(\mathrm{pH}=9.8)$ in the presence of plant roots $(\mathrm{pH}=9.4)$ and compost amendment $(\mathrm{pH}=8.5)$. Bulk density of the potting soil and treatments was significantly lower (average of different plant types $=0.78 \mathrm{~g} \mathrm{~cm}^{-3}$ ) than the parent material (average of different plant types $=1.83 \mathrm{~g} \mathrm{~cm}^{-3}$ ), and even within the parent material and treatments, significant differences in mean bulk density were also observed. Potting soil and treatments were held on average $50 \%$ moisture and were significantly higher than the parent material soil with or without compost. Carbon and nitrogen estimates were also significantly higher in the potting soil (average of different plant types $=314 \mu \mathrm{g} \mathrm{mg}^{-1}$ ) than the parent material and parent material with compost treatments (average of different plant types $=14.24 \mu \mathrm{g} \mathrm{mg}^{-1}$ ). The marginal soil characteristic of the parent material (lack of structure, high bulk density, low moisture holding capacity, and low nutrients), as compared to the potting soil, primarily separates the treatments into the two broad groups, as observed in the principal component plot showing variation in soil samples and irrigation water (Figure 3). The average moisture content of the soils ranged from $50 \%$ in potting soil, $3.33 \%$ in basalt soil amended with compost, and $5.33 \%$ in basalt soil.

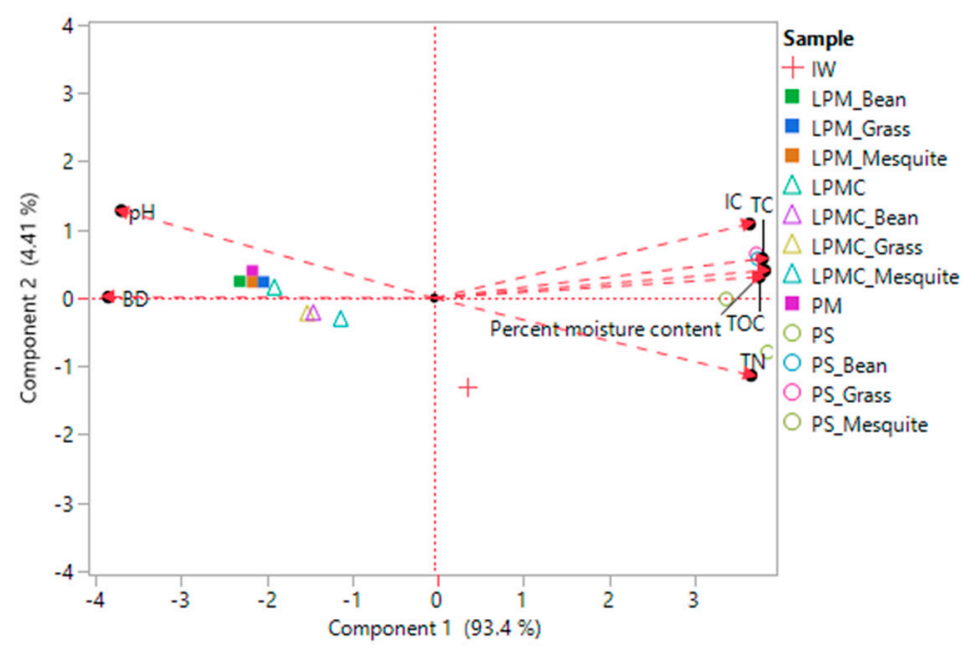

Figure 3. Variation observed in the physico-chemical characteristics of triplicate soil-plant treatments and water samples after 30 days, plotted as principle component of variation superimposed by variable loadings. Points are averages of three replicates. Abbreviations: LPM (LEO Parent Material), LPMC (LEO Parent Material + Compost), PS (Potting Soil), and the plant species follow the soil material type, IW (Irrigation Water), TC (Total Carbon), TOC (Total Organic Carbon), IC (Total Inorganic Carbon), TN (Total Nitrogen), and BD (Bulk Density).

For the LEO parent material, significant differences were not observed for the bare soil or those with plants, while parent material amended with compost had a significant increase in carbon (total, organic, inorganic) and nitrogen concentrations for each plant type. It is interesting to note that while plant germination and growth differences did not differ significantly between basalt material with or without compost, the soil characteristics between the two treatments differed significantly. Therefore, soil characteristics likely start to change in these incipient soils within a month when amended with compost, though the effects are not parallelly observable in aboveground plant growth dynamics, suggesting that abiotic shifts in soil characteristics may not have linear observable shifts on plant growth. 


\subsection{Composition of Microbial Communities}

High-throughput $16 \mathrm{~S}$ rRNA gene amplicon sequencing was performed to evaluate soil microbial community composition. A total of 5955 Operational Taxonomic Unit (OTUs) were obtained across basalt parent material samples and potting soil samples. The DNA extracts from compost-amended LEO soil samples failed to amplify and are therefore absent from the analyses. Despite treating the compost samples with a $5.5 \mathrm{M}$ guanidine thiocyanate (GTC) wash to remove PCR-interfering humic matter [54] and attempting to amplify the samples twice, the compost sample DNA extracts failed to amplify. It is likely that the DNA was coextracted with PCR-inhibiting material (either humic acid and/or ions that bind to DNA) in these samples. Therefore, for this section of the results, the samples were separated into the two broad soil treatments: Parent material and potting soil.

A total of 27 phyla were observed across the samples (Supplementary Figure S1). The top ten phyla detected were Acidobacteria $(0.8 \%-5.7 \%)$, Actinobacteria $(2.6 \%-26 \%)$, Bacteroidetes $(2.1 \%-11.1 \%)$, Chloroflexi $(0.6 \%-2.5 \%)$, Cyanobacteria $(1.1 \%-3.7 \%)$, Firmicutes $(1.4 \%-7.9 \%)$, Gemmatimonadetes $(0.7 \%-2.8 \%)$, Planctomycetes $(0.7 \%-5.0 \%)$, Proteobacteria $(43.9 \%-60.7 \%)$, and Verrucomicrobia $(1.5 \%-16.8 \%)$. Proteobacteria were the most abundant phyla in both soil types. The potting soil showed Actinobacteria $(26 \%)$ to be the second most abundant phyla, but its abundance was reduced in the soil + plus plant $(11.1 \%-14.9 \%)$. Within the potting soil samples, an increase in Verrucomicrobial OTUs was also observed in the soils with plants $(5.8 \%-11.3 \%)$ from $1.5 \%$ in bare soil. The abundance of Verrucomicrobia (Mesquite $>$ Grass $>$ Bean) showed a similar relative abundance pattern in the basalt soil to that in potting soil, which could be indicative of plant-specific microbial community response.

A total of 71 classes were observed across the samples (Supplementary Figure S2). The top ten classes detected were [Pedosphaerae] $(0.8 \%-5.3 \%)$, [Saprospirae] $(0.7 \%-9.1 \%)$, Alphaproteobacteria (22.2\%-42.7\%), Actinobacteria (1.1\%-16.3\%), Betaproteobacteria (2.3\%-14.4\%), Bacilli $(1.6 \%-7.6 \%)$, Deltaproteobacteria $(0.2 \%-4.9 \%)$, Gammaproteobacteria $(2.5 \%-19.6 \%)$, Opitutae $(0.6 \%-9.8 \%)$, and Thermoleophilia (0.3\%-6.2\%) (Figure 4). The Alphaproteobacteria were the most abundant class in both soil types. The potting soil showed Gammaproteobacteria (19.6\%) to be the second most abundant class, but its abundance was reduced in the soil plus plant (5.6\%-9.6\%). In addition, a decrease in Acidobacteriia, Actinoobacteria, Betaproteobacteria, and Thermophilia OTUs was observed in potting soils with plants. Within the potting soil samples, OTUs of [Pedosphaerae], [Saprospirae], [Spartobacteria], Acidobacteria-6, Alphaproteobacteria, Chloroplast, Cytophagia, Deltaproteobacteria, Opitutae, Phycisphaerae, and Planctomycetia were observed to increase in the soils with plants. The observed shift in microbial community abundances is likely a result of plant establishment in the potting soils. The number of different classes in the bean plant was the lowest compared to grass and mesquite in both basalt and potting soil, suggesting that plant-specific microbial community establishment during plant growth.

Furthermore, within the basalt soil type, the bean plant soil had low abundance of Acidobacteria $(0.8 \%)$, Armatimonadetes $(0.3 \%)$, Chloroflexi $(0.6 \%)$, Gemmatimonadetes $(0.7 \%)$, and Planctomycetes $(0.7 \%)$ when compared to the grass and mesquite plant soils. However, within the basalt soil type, Alphaproteobacteria (42.7\%) and Actinobacteria (16.3\%) had a higher abundance in the bean plant, which was much higher than in grass $(27.4 \%, 1.8 \%)$ and mesquite $(22.2 \%, 1.1 \%)$. The bean plant is a legume and is therefore known to have nitrogen fixation mediated by nitrogen-fixing bacteria in the plant root nodules $[55,56]$. Interestingly, over the recent years, multiple studies have highlighted the role of many nitrogen-fixing actinobacterial taxa, as highlighted in a review by Gtari et al., 2012 [57], as well as the filamentous nature of actinobacterial groups promoting successful colonization of oligotrophic land surfaces [58]. 


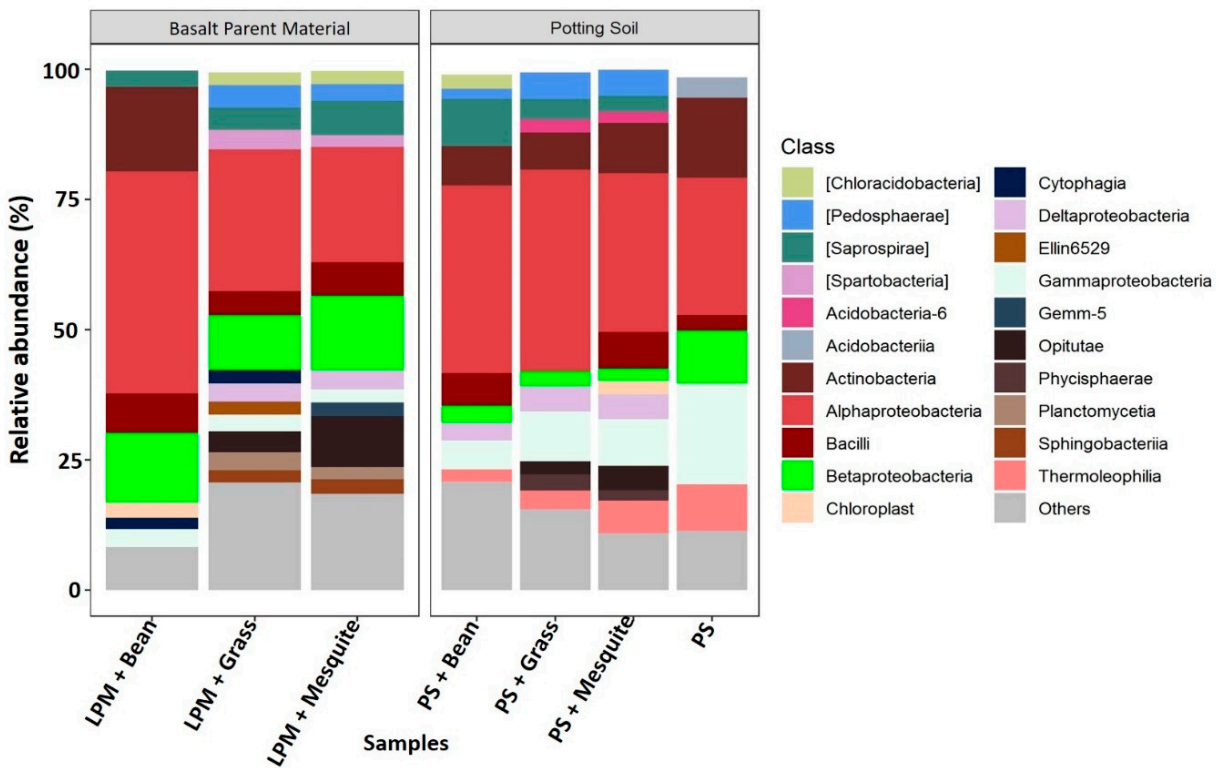

Figure 4. Relative proportions of bacterial community at the class level. Classes representing more than $2 \%$ in all samples are summarized, and the remaining are indicated as others in the figure. Abbreviations: LPM (LEO Parent Material), PS (Potting Soil), and the plant species follow the soil material type. The sample without plant species name is a control sample.

Out of a total of 343 identified different genera, 191 were unclassified genera. The top ten genera in the basalt soil were Agromyces (0.94\%-10.4\%), Bacillus (5.76\%-10.0\%), Balneimonas (4.1\%-7.328\%), Bdellovibrio (1.0\%-4.04\%), Flavisolibacter (1.9\%-4.2\%), Methyloversatilis $(1.9 \%-13.9 \%)$, Opitutus $(0.63 \%-6.5 \%)$, Sediminibacterium (2.2\%-5.6\%), Sinorhizobium (24.6\%), and Sphingopyxis $(3.0 \%-8.5 \%)$. The top ten genera identified in the potting soil were Bacillus $(0.89 \%-4.41 \%)$, Devosia $(6.12 \%-10.74 \%)$, Kaistobacter $(1.3 \%-20.1 \%)$, Luteibacter $(0.1 \%-17.3 \%)$, Mycobacterium $(1.3 \%-6.4 \%)$, Opitutus $(3.9 \%-10.5 \%)$, Rhodoplanes $(12.0 \%-30.2 \%)$, Sediminibacterium $(0.4 \%-5.0 \%)$, Sphaerisporangium $(2.3 \%-4.2 \%)$, and Streptomyces $(3.9 \%-9.4 \%)$. The genera Alicyclobacillus $(0.2 \%-3.6 \%)$ and Sphaerisporangium $(2.34 \%-4.2 \%)$ were only detected in the potting soil, whereas the basalt soil had the following unique genera: Agromyces (0.94\%-10.4\%), Balneimonas (3\%-7.3\%), Methyloversatilis (1.9\%-13.5\%), Pleomorphomonas ( $0.5 \%-2.1 \%)$, and Renibacterium $(0.13 \%-3.0 \%)$.

The DNA extracted from the LEO basalt parent material without plants did not have a high enough number of sequences to pass the sequence analysis quality control in this study. However, as a standalone analysis for visual comparison (Supplementary Figure S3), the parent material community consists of $62 \%$ Bacteroidetes, followed by $16 \%$ Firmicutes, and less than 10\% Proteobacteria. This suggests a dramatic month-long shift in the soil microbial community composition of the basalt soil. Since the seeds were not sterilized before planting, it cannot be ruled out that the seeds may have contributed to the increase in microbial community diversity. We posit that a combination of the parent material, dust and irrigation water input, and seeds provided a heterogeneous initial composition, and the root exudates further altered the availability and quality of carbon compounds that increased community richness and introduced an abundance of new taxa in the incipient basalt material.

A comparison of species richness and Shannon's diversity index after rarefaction showed minor differences in the composition of the microbial community (Figure 5). Richness in potting soil samples had a wider range from 394-728 compared to parent material samples, 475-672. Potting soil plus bean had the highest richness of 728, while potting soil plus mesquite had the lowest richness of 394. Shannon's indices in LEO parent material samples ranged from 4.8-5.8 versus 4.7-5.7 in potting soils. The richness and Shannon's index of microbial communities were not significantly different between the soil types and plant types. Additionally, the percent richness across samples ranged from $10 \%-18.4 \%$, whereas \% Shannon's index ranged from $12.7 \%-15.6 \%$ (Supplemental Table S2). 


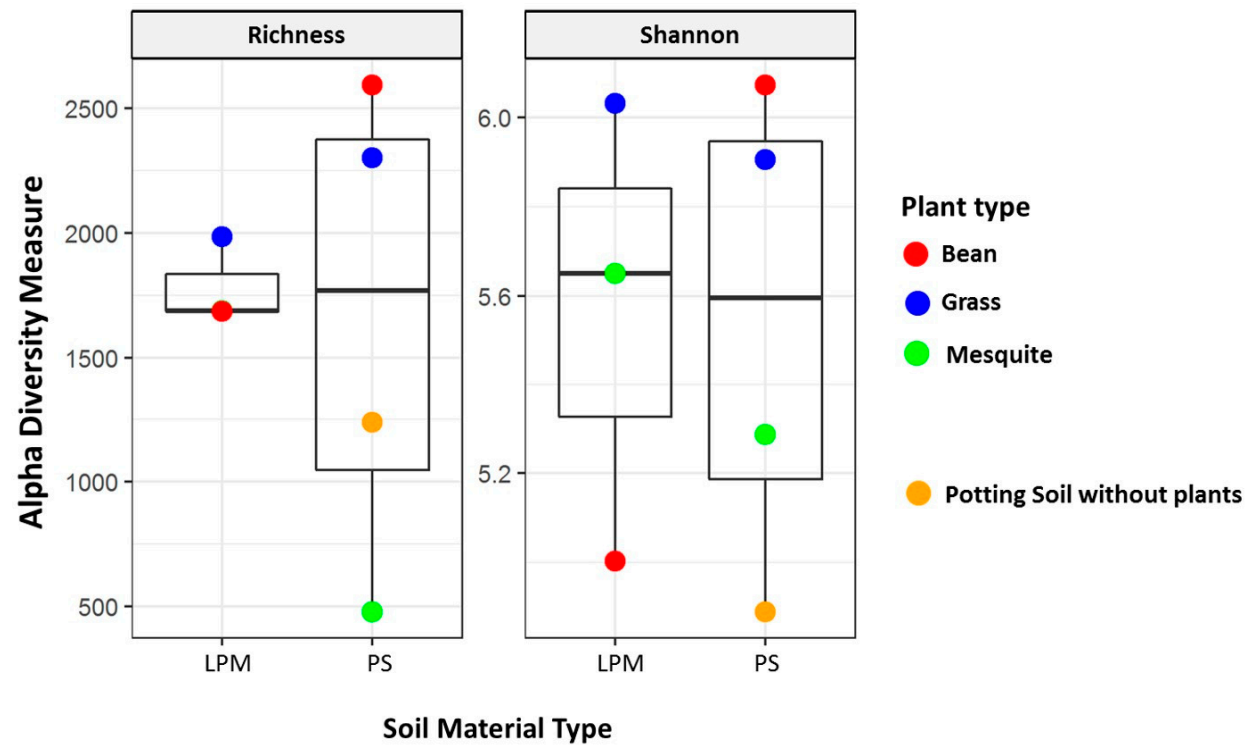

Figure 5. Alpha diversity in the studied soils represented by richness and Shannon's index. The plant types-bean, grass, and mesquite-are indicated by the colors red, blue, and green. The potting soil control (without plant) is represented by the color yellow. The soil material is indicated as LPM (LEO Parent Material) and PS (Potting Soil).

A principal coordinate analysis (PCoA) plot of the Bray-Curtis dissimilarity distance matrix demonstrated the differences in microbial communities between the soil types (Figure 6). The first two PCoA axes together explained $65.3 \%$ of the variation in the microbial communities. The samples from each soil type grouped distinctly separate from the control sample of potting soil plus plant samples. Additionally, PERMANOVA analysis revealed that microbial communities in LEO parent material and potting soil were significantly different $(P=0.03)$ with a $\mathrm{R}^{2}$ of 0.47 , suggesting $47 \%$ of the variation in the microbial communities to be explained by the soil material type.

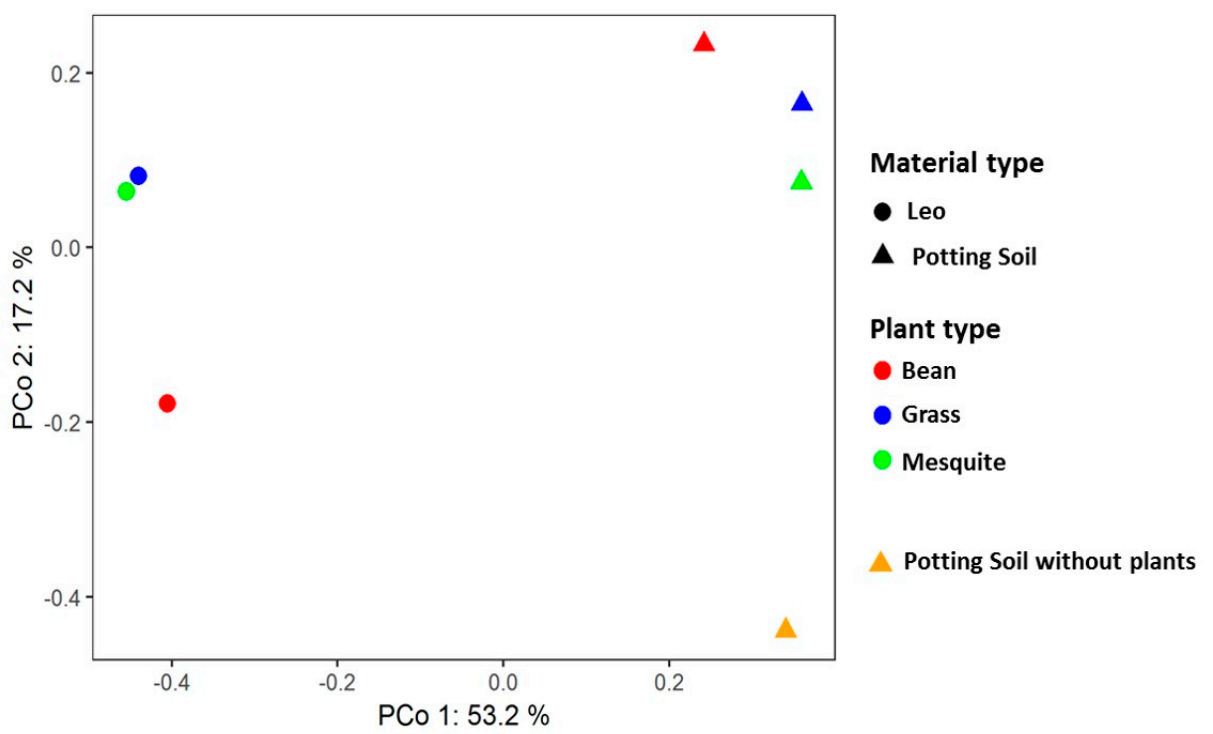

Figure 6. A Principle Coordinate Analysis (PCoA) plot based on the Bray-Curtis distance matrix showing similarity of the bacterial and archaeal community in the studied soil material type. The first two PCoA axes together explain $65.3 \%$ of the variation in the microbial community based on the soil material type. The non-parametric multivariate analysis of variance (PERMANOVA) of soil type was significantly different $(P=0.03)$. 


\subsection{Microbial Communities and Environmental Variables}

The PERMANOVA and Mantel test were carried out to decipher linkages between soil microbial communities and environmental variables, and between soil microbial communities and plant attributes (Table 1). PERMANOVA as well as the Mantel test demonstrated that the majority of the soil factors influenced the microbial communities. Among these soil factors, pH, TC, TIC, TOC, TN, moisture content, bulk density, and soil material type exhibited significant $(P<0.05)$ associations with microbial communities. The $\mathrm{R}^{2}$ values for the environmental variables ranged from $0.42-0.47$, representing the $42 \%-47 \%$ contribution of the variables towards the microbial community. These soil factors that exhibited significant correlations had strong correlation values (r) ranging from 0.69 (TIC) to $0.91(\mathrm{pH})$. The soil material type also had a strong significant $r$ value of 0.87 , thus indicating that the microbial community shifts were significantly correlated with the soil material type. Plant attributes did not show significant interactions with the soil microbial communities for the duration of the experiment.

Table 1. Correlations between the environmental variables and plant attributes with the Bray-Curtis dissimilarity index using a non-parametric multivariate analysis of variance (PERMANOVA) and Mantel test.

\begin{tabular}{ccccc}
\hline & \multicolumn{2}{c}{ PERMANOVA } & \multicolumn{2}{c}{ Mantel Test } \\
\hline Environmental variables & $\mathbf{R}^{\mathbf{2}}$ & $\boldsymbol{P}$ & $\mathbf{r}$ & $\boldsymbol{P}$ \\
pH & 0.46 & $\mathbf{0 . 0 0 2}$ & 0.91 & $\mathbf{0 . 0 0 2}$ \\
TC & 0.47 & $\mathbf{0 . 0 0 7}$ & 0.87 & $\mathbf{0 . 0 1 2}$ \\
TN & 0.45 & $\mathbf{0 . 0 2}$ & 0.9 & $\mathbf{0 . 0 0 2}$ \\
TOC & 0.47 & $\mathbf{0 . 0 0 2}$ & 0.85 & $\mathbf{0 . 0 0 6}$ \\
TIC & 0.42 & $\mathbf{0 . 0 2}$ & 0.69 & $\mathbf{0 . 0 2 3}$ \\
Moisture content & 0.47 & $\mathbf{0 . 0 1 8}$ & 0.86 & $\mathbf{0 . 0 3 9}$ \\
Bulk density & 0.43 & $\mathbf{0 . 0 3}$ & 0.81 & $\mathbf{0 . 0 1 7}$ \\
Soil material type & 0.47 & $\mathbf{0 . 0 3 5}$ & 0.87 & $\mathbf{0 . 0 3 4}$ \\
\hline Plant attributes & $\mathbf{R}^{\mathbf{2}}$ & $\boldsymbol{P}$ & $\mathbf{r}$ & $\boldsymbol{P}$ \\
Germination rate & 0.15 & 0.474 & 0.02 & 0.413 \\
Plant height & 0.21 & 0.232 & 0.10 & 0.310 \\
Wet aboveground biomass & 0.17 & 0.429 & -0.16 & 0.660 \\
Dry aboveground biomass & 0.17 & 0.416 & -0.14 & 0.605 \\
Plant type & 0.39 & 0.799 & 0.00 & 0.452 \\
\hline
\end{tabular}

Mantel coefficient ( $\mathrm{r}$ ) ranges from -1 to +1 . A value of -1 indicates strong negative correlation, a value of +1 indicates strong positive correlation, and 0 means no correlation. Significant values $(P<0.05)$ are in bold.

An observable difference is present in aboveground plant attributes and belowground microbial community structure shifts. Therefore, as with the abiotic changes in the soil, belowground biotic changes (in this case, microbial community structure) had non-linear associations with plant establishment and growth for the initial time of growth captured in our study. This time-lag between aboveground and belowground shift may be a critical point when evaluating and predicting temporal feedbacks between plant-soil-microbe interactions [59]. These results are useful in informing future directions of our study, where plant establishment and growth in the basalt material can be studied over a longer duration, followed by periodic sampling of soil and plant material to temporally identify linear versus non-linear associations between plant-soil-microbe interactions.

\subsection{Predicted Functional Potential of Microbial Community}

The OTUs were utilized to predict the functional potential of the soil microbial community in LEO and potting soil samples. Using FAPROTAX analyses, 59 predicted functions were identified. A subset of 24 functions were further evaluated for their relative profiles in the different soil samples (Figure 7). These functions were chosen to reflect broad carbon fixation/utilization mechanisms (autotrophy versus heterotrophy), and nitrogen cycling metabolisms. Like the microbial community differences, the LEO and potting soils also demonstrated differences in their functional potential. Chemoheterotrophy was 
the most abundant identified function within LEO soils, while photoheterotrophy and anoxygenic photoautotrophy were higher in the potting soils.

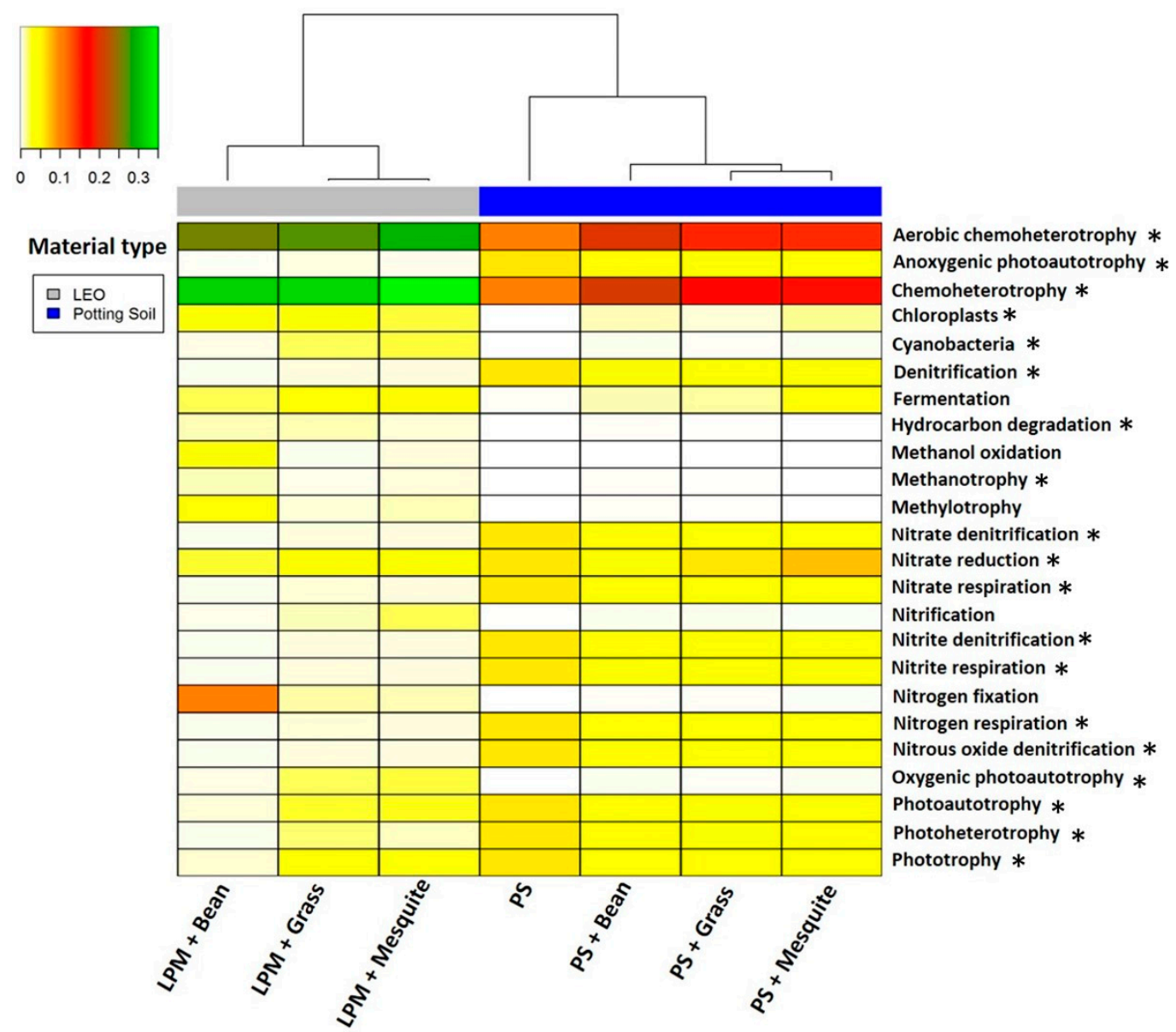

Figure 7. A heatmap showing relative abundance of the selected predicted functional potential of the microbial community using FAPROTAX analysis in the studied soil materials. The relative abundance ranges from 0 to 0.35 and is represented by white (0-0.025), red (0.026-0.1), yellow (0.11-0.21), and green (0.21-0.35), respectively. Abbreviations: LPM (LEO Parent Material), PS (Potting Soil), and the plant species follow the soil material type. As per the Mantel test, nineteen functions (represented by *) were significantly different $(P<0.05)$ between the soil types with the exception of fermentation, methanol oxidation, methylotrophy, nitrification, and nitrogen fixation.

The majority of the 24 functions were significantly different between the soil types (Table 2) with the exception of fermentation, methanol oxidation, methylotrophy, nitrification, and nitrogen fixation. The Mantel test showed a strong correlation of the predicted functions with soil type material $(\mathrm{r}=0.89$, $P=0.026)$. The hierarchical cluster grouped the samples according to their soil types, indicating the soil-type-specific functional capacity. The grass and mesquite samples in both LEO parent material and potting soil clustered closely compared to the bean. The basalt soil plus bean sample had the highest nitrogen fixation capacity among all samples. In contrast, the potting soils did not have high abundance of nitrogen fixation, but presented higher abundance of other nitrogen cycling pathways (denitrification, reduction, and respiration) as compared to the basalt material soils. The function of fermentation was predicted to be higher in the basalt material, which suggests that the basalt material may constitute fermentators that fix carbon $[60,61]$. While we did not observe high autotrophic predictions for the incipient basalt material, the presence of microbes in this low-carbon soil and the overall increase in organic carbon concentration is evidence of carbon-fixation mechanisms at play. 
Furthermore, the higher predictive heterotrophic activity in basalt soils could be attributed to the likely diminished autotrophic activity of the Cyanobacteria during plant colonization, resulting in the availability of fixed plant carbon for heterotrophs [62]. Additionally, we propose a second hypothesis that heterotrophy rates far exceed autotrophy rates in these low-carbon environments. It may be likely that as soon as autotrophs are able to fix carbon and produce by-products, the heterotrophs utilize the fixed carbon and proliferate. The FAPROTAX results should be treated with caution, as they do not confirm the presence/absence of in situ microbial metabolisms. However, these results do serve as a starting point to generate further hypotheses of soil-microbe interactions and metabolic strategies potentially at play in low-carbon versus nutrient-rich soils.

Table 2. Analysis of variance showing statistical differences in predicted Functional Annotation of Prokaryotic Taxa (FAPROTAX) functions between soil types.

\begin{tabular}{ccc}
\hline Predicted Functions & F & $\boldsymbol{P}$ \\
\hline Aerobic chemoheterotrophy & 28.6 & $\mathbf{0 . 0 0 3}$ \\
Anoxygenic photoautotrophy & 87.8 & $\mathbf{0 . 0 0 0 2}$ \\
Chemoheterotrophy & 40.2 & $\mathbf{0 . 0 0 1}$ \\
Chloroplasts & 26.5 & $\mathbf{0 . 0 0 4}$ \\
Cyanobacteria & 7.6 & $\mathbf{0 . 0 4 0}$ \\
Denitrification & 84.1 & $\mathbf{0 . 0 0 0 3}$ \\
Fermentation & 4.3 & 0.094 \\
Hydrocarbon degradation & 38.1 & $\mathbf{0 . 0 0 2}$ \\
Methanol oxidation & 2.8 & 0.157 \\
Methanotrophy & 10.7 & $\mathbf{0 . 0 2 2}$ \\
Methylotrophy & 3.9 & 0.106 \\
Nitrate denitrification & 84.1 & $\mathbf{0 . 0 0 0 3}$ \\
Nitrate reduction & 12.0 & $\mathbf{0 . 0 1 8}$ \\
Nitrate respiration & 82.8 & $\mathbf{0 . 0 0 0 3}$ \\
Nitrification & 4.2 & 0.096 \\
Nitrite denitrification & 84.1 & $\mathbf{0 . 0 0 0 3}$ \\
Nitrite respiration & 84.4 & $\mathbf{0 . 0 0 0 3}$ \\
Nitrogen fixation & 2.4 & 0.185 \\
Nitrogen respiration & 82.8 & $\mathbf{0 . 0 0 0 3}$ \\
Nitrous oxide denitrification & 84.1 & $\mathbf{0 . 0 0 0 3}$ \\
Oxygenic photoautotrophy & 7.6 & $\mathbf{0 . 0 4 0}$ \\
Photoautotrophy & 20.3 & $\mathbf{0 . 0 0 6}$ \\
Photoheterotrophy & 45.1 & $\mathbf{0 . 0 0 1}$ \\
Phototrophy & 7.9 & $\mathbf{0 . 0 3 7}$ \\
\hline
\end{tabular}

An F-value closer to 1 indicates that the means of the two groups are equal. A higher F-value indicates that the means of the two groups are not identical. Significant values $(P<0.05)$ are in bold.

\section{Conclusions}

The ability to use marginal soils is crucial to the framework of Land Degradation Neutrality. In this study, we evaluated whether marginal incipient basaltic soil will be able to support plant growth under ideal growth conditions. Here, plants native to the geographical area and climate of a marginal incipient basaltic soil material, with and without organic amendment, were evaluated for their germination and growth attributes. Comparisons of soil microbial communities and plant attributes were made between the incipient soil and a commercially available potting soil. The results show that marginal incipient basaltic soil can support native plant growth and that distinct soil microbial communities develop in these soils alongside plant establishment. Furthermore, nonlinear associations between abiotic shifts in soil characteristics, microbial community compositional changes, and plant growth parameters exhibited.

A direct outcome of this study is being applied to current experiments being conducted at the Landscape Evolution Observatory to establish plants and monitor the co-evolving hydrobiogeochemical signatures in the incipient landscapes. As a future direction, we propose detailed experiments with 
longer growth periods and different combinations of marginal soils with and without amendments to evaluate the capacity of such soils to support and sustain plant growth. Furthermore, additional cleaning steps to obtain clean DNA from the basalt plus compost samples may be evaluated. With LEO experiments, the use of compost may also be considered to aid vegetation establishment in the hillslopes. Additionally, an approach of sourcing and using native seeds can be a collaborative exercise between scientists and social scientists to involve and evaluate native cultures' knowledge base to answer modern-day sustainability issues.

Supplementary Materials: The following are available online at http://www.mdpi.com/2071-1050/12/10/4209/s1, Supplementary Table S1 Raw data (soil characterization and plant attributes). Supplementary Table S2: Alpha diversity measurements represented by richness and Shannon's diversity index and the \% richness and Shannon's index differences across samples. Supplementary Figure S1. Relative abundance of microbial community at the phyla level. Abbr. LPM (LEO Parent Material), PS (Potting Soil). Supplementary Figure S2: Relative abundance of bacterial and archaeal community at the class level. A total of 71 classes were identified. Abbreviations: LPM (LEO Parent Material), PS (Potting Soil), and the plant species follow the soil material type. Sample without a plant species name is a control sample. Supplementary Figure S3. Relative abundance of the incipient basaltic parent material.

Author Contributions: Conceptualization, A.S.; Methodology, A.S. and A.J.; Formal Analysis, A.S., A.J., and P.K.; Investigation, A.S., P.K., and A.J.; Resources, P.A.T. and R.M.; Data Curation, A.S. and P.K.; Writing-Original Draft Preparation, A.S. and P.K.; Writing-Review and Editing, A.S., A.J., and P.A.T.; Visualization, A.S., P.K., and A.J.; Supervision, A.S.; Project Administration, A.S.; Funding Acquisition, P.A.T. and R.M. All authors have read and agreed to the published version of the manuscript.

Funding: This research was funded by the National Science Foundation through a Center for Integrated Access Networks (CIAN) grant \#EEC-0812072 and Research Experience for Undergraduates (REU) site award \#EEC-1359163 and \#EEC-165910.

Acknowledgments: A.J. would like to acknowledge Integrated Optics for Undergraduate Native American (IOU-NA) REU Program directors Amee Hennig, Alison Hoff-Lohmeier, and Emily Lynch for the opportunity to carry out this research. A.S. and A.J. would like to thank Karen Serrano and Edward Hunt for analyzing soil chemical characteristics, as well as Emalee Eisenhauer, Roopkamal Kaur, Katarena Matos, Genesis Matos, Antonio Alveres Meira-Neto, and Scott Alexander White for their support during the experimental set-up and sampling. A.S. and A.J. also thank Katerina Dontsova and Kevin E. Bonine for facilitating the REU program at the University of Arizona.

Conflicts of Interest: "The authors declare no conflict of interest." "The funders had no role in the design of the study; in the collection, analyses, or interpretation of data; in the writing of the manuscript, or in the decision to publish the results".

\section{References}

1. Weil, R.R.; Brady, N.C. The Nature and Properties of Soils, 15th ed.; Pearson: London, UK, 2017; ISBN 0133254488.

2. Pimentel, D. Soil erosion: A food and environmental threat. Environ. Dev. Sustain. 2006, 8, 119-137. [CrossRef]

3. O'geen, A.T.; Schwankl, L.J. University of California Davis, Division of Agriculture and Natural Resources, Publication 8196; University of California: Davis, CA, USA, 2006.

4. World Health Organization. Land Degradation and Desertification. 2012. Available online: http://www.who. int/globalchange/ecosystems/desert/en/ (accessed on 6 April 2018).

5. UNCCD/Science-Policy Interface. Land in Balance the Scientific Conceptual Framework for Land Degradation Neutrality Conceptual Framework for Land Degradation Neutrality (LDN); United Nations Convention to Combat Desertification: Bonn, Germany, 2016.

6. Orr, B.J.; Cowie, A.L.; Sanchez, V.M.C.; Chasek, P.; Crossman, N.D.; Erlewein, A.; Louwagie, G.; Maron, M.; Metternicht, G.I.; Minelli, S.A.E.; et al. Scientific Conceptual Framework for Land Degradation Neutrality: A Report of the Science-Policy Interface; United Nations Covention to Combat Desertification: Bonn, Germany, 2017.

7. Montoya-Tangarife, C.; de la Barrera, F.; Salazar, A.; Inostroza, L. Monitoring the effects of land cover change on the supply of ecosystem services in an urban region: A study of Santiago-Valparaíso, Chile. PLoS ONE 2017, 12, e0188117. [CrossRef] [PubMed]

8. Valentín-Vargas, A.; Root, R.A.; Neilson, J.W.; Chorover, J.; Maier, R.M. Environmental factors influencing the structural dynamics of soil microbial communities during assisted phytostabilization of acid-generating mine tailings: A mesocosm experiment. Sci. Total Environ. 2014, 500-501, 314-324. [CrossRef] [PubMed] 
9. Honeker, L.K.; Neilson, J.W.; Root, R.A.; Gil-Loaiza, J.; Chorover, J.; Maier, R.M. Bacterial rhizoplane colonization patterns of buchloe dactyloides growing in metalliferous mine tailings reflect plant status and biogeochemical conditions. Microb. Ecol. 2017, 74, 853-867. [CrossRef] [PubMed]

10. Valentín-Vargas, A.; Neilson, J.W.; Root, R.A.; Chorover, J.; Maier, R.M. Treatment impacts on temporal microbial community dynamics during phytostabilization of acid-generating mine tailings in semiarid regions. Sci. Total Environ. 2018, 618, 357-368. [CrossRef]

11. Grandlic, C.J.; Mendez, M.O.; Chorover, J.; Machado, B.; Maier, R.M. Plant growth-promoting bacteria for phytostabilization of mine tailings. Environ. Sci. Technol. 2008, 42, 2079-2084. [CrossRef] [PubMed]

12. Mendez, M.O; Maier, R.M. Phytoremediation of mine tailings in temperate and arid environments. Rev. Environ. Sci. Biotechnol. 2008, 7, 47-59. [CrossRef]

13. Smith, S.W.; Ross, K.; Karlsson, S.; Bond, B.; Upson, R.; Davey, A. Going native, going local: Revegetating eroded soils on the Falkland Islands using native seeds and farmland waste. Restor. Ecol. 2017, 26, 134-144. [CrossRef]

14. Gould, I.J.; Quinton, J.N.; Weigelt, A.; De Deyn, G.B.; Bardgett, R.D. Plant diversity and root traits benefit physical properties key to soil function in grasslands. Ecol. Lett. 2016, 19, 1140-1149. [CrossRef]

15. Debenport, S.J.; Assigbetse, K.; Bayala, R.; Chapuis-Lardy, L.; Dick, R.P.; McSpadden Gardener, B.B. Shifting populations in the root-zone microbiome of millet associated with enhanced crop productivity in the Sahel. Appl. Environ. Microbiol. 2015. [CrossRef] [PubMed]

16. Tittonell, P.; Scopel, E.; Andrieu, N.; Posthumus, H.; Mapfumo, P.; Corbeels, M.; van Halsema, G.E.; Lahmar, R.; Lugandu, S.; Rakotoarisoa, J.; et al. Agroecology-based aggradation-conservation agriculture (ABACO): Targeting innovations to combat soil degradation and food insecurity in semi-arid Africa. Field Crops Res. 2012, 132, 168-174. [CrossRef]

17. Abd-Elmabod, S.; Bakr, N.; Muñoz-Rojas, M.; Pereira, P.; Zhang, Z.; Cerdà, A.; Jordán, A.; Mansour, H.; De la Rosa, D.; Jones, L. Assessment of soil suitability for improvement of soil factors and agricultural management. Sustainability 2019, 11, 1588. [CrossRef]

18. Hernandez, R.R.; Debenport, S.J.; Leewis, M.C.C.E.; Ndoye, F.; Nkenmogne, K.I.E.; Soumare, A.; Thuita, M.; Gueye, M.; Miambi, E.; Chapuis-Lardy, L.; et al. The native shrub, Piliostigma reticulatum, as an ecological "resource island" for mango trees in the Sahel. Agric. Ecosyst. Environ. 2015, 204, 51-61. [CrossRef]

19. Nunes, J.S.; Araujo, A.S.F.; Nunes, L.A.P.L.; Lima, L.M.; Carniero, R.F.V.; Salviano, A.A.C.; Tsai, S.M. Impact of land degradation on soil microbial biomass and activity in Northeast Brazil. Pedosphere 2012, 22, 88-95. [CrossRef]

20. Zhang, H.; Wang, R.; Chen, S.; Qi, G.; He, Z.; Zhao, X. Microbial taxa and functional genes shift in degraded soil with bacterial wilt. Sci. Rep. 2017, 7, 39911. [CrossRef] [PubMed]

21. Araújo, A.S.F.; Borges, C.D.; Tsai, S.M.; Cesarz, S.; Eisenhauer, N. Soil bacterial diversity in degraded and restored lands of Northeast Brazil. Antonie Van Leeuwenhoek 2014, 106, 891-899. [CrossRef]

22. van der Heijden, M.G.A.; Bardgett, R.D.; van Straalen, N.M. The unseen majority: Soil microbes as drivers of plant diversity and productivity in terrestrial ecosystems. Ecol. Lett. 2008, 11, 296-310. [CrossRef]

23. Delgado-Baquerizo, M.; Maestre, F.T.; Reich, P.B.; Jeffries, T.C.; Gaitan, J.J.; Encinar, D.; Berdugo, M.; Campbell, C.D.; Singh, B.K. Microbial diversity drives multifunctionality in terrestrial ecosystems. Nat. Commun. 2016, 7, 10541. [CrossRef]

24. Jenny, H.K. Factors of Soil Formation: A System of Quantitative Pedology; Tata McGraw Hill: New York, NY, USA, 1941.

25. Dauber, J.; Brown, C.; Fernando, A.L.; Finnan, J.; Krasuska, E.; Ponitka, J.; Styles, D.; Thrän, D.; Jan, K.; Groenigen, V.; et al. Bioenergy from "surplus" land: Environmental and socio-economic implications. BioRisk 2012, 7, 5-50. [CrossRef]

26. Mendez, M.O.; Neilson, J.W.; Maier, R.M. Characterization of a bacterial community in an abandoned semiarid lead-zinc mine tailing site. Appl. Environ. Microbiol. 2008, 74, 3899-3907. [CrossRef]

27. Ciria, C.; Sanz, M.; Carrasco, J.; Ciria, P. Identification of arable marginal lands under rainfed conditions for bioenergy purposes in Spain. Sustainability 2019, 11, 1833. [CrossRef] 
28. Volkmann, T.H.M.; Sengupta, A.; Pangle, L.A.; Dontsova, K.; Barron-Gafford, G.A.; Harman, C.J.; Niu, G.-Y.; Abramson, N.; Meira-Neto, A.A.; Wang, Y.; et al. Controlled experiments of hillslope coevolution at the biosphere 2 landscape evolution observatory: Toward prediction of coupled hydrological, biogeochemical, and ecological change. In Hydrology of Artificial and Controlled Experiments; Intech Open Limiited: London, UK, 2017; pp. 25-74.

29. Sengupta, A.; Pangle, L.A.; Volkmann, T.H.M.; Dontsova, K.; Troch, P.A.; Meira-neto, A.A.; Neilson, J.W.; Hunt, E.A.; Chorover, J.; Zeng, X.; et al. Advancing understanding of hydrological and biogeochemical interactions in evolving landscapes through controlled experimentation at the landscape evolution observatory. In Terrestrial Ecosystems Research Infrastructure: Challenges and Opportunities; Chabbi, A., Loescher, H.W., Eds.; CRC Press, Taylor and Francis Group: Boca Raton, FL, USA, 2017; pp. 83-118.

30. Pangle, L.A.; DeLong, S.B.; Abramson, N.; Adams, J.; Barron-Gafford, G.A.; Breshears, D.D.; Brooks, P.D.; Chorover, J.; Dietrich, W.E.; Dontsova, K.; et al. The landscape evolution observatory: A large-scale controllable infrastructure to study coupled Earth-surface processes. Geomorphology 2015, 244, 190-203. [CrossRef]

31. Pohlmann, M.; Dontsova, K.; Root, R.; Ruiz, J.; Troch, P.; Chorover, J. Pore water chemistry reveals gradients in mineral transformation across a model basaltic hillslope. Geochem. Geophys Geosystems 2016, 17, 2054-2069. [CrossRef]

32. Sengupta, A.; Stegen, J.C.; Nielson, J.W.; Meira-Neto, A.; Wang, Y.; Troch, P.A.; Chorover, J.; Maier, R.M. Assessment of microbial community patterns under incipient conditions in a basalt soil system. J. Geophys. Res. Biogeosci. 2019, 124, 941-958. [CrossRef]

33. Native Seeds/SEARCH—Home. Available online: https://www.nativeseeds.org/ (accessed on 29 August 2017).

34. Sengupta, A.; Wang, Y.; Meira Neto, A.A.; Matos, K.A.; Dontsova, K.; Root, R.; Neilson, J.W.; Maier, R.M.; Chorover, J.; Troch, P.A. Soil lysimeter excavation for coupled hydrological, geochemical, and microbiological investigations. J. Vis. Exp. 2016, 2016. [CrossRef] [PubMed]

35. Jim, A.; Sengupta, A. Assessing the ability of incipient basaltic soil to support plants native to Southwestern United States. J. Undergrad. Res. 2018, IX, 30-33.

36. Duke, J.A. Phaseolus vulgaris L. In Handbook of Energy Crops. Available online: https://www.hort.purdue.edu/ newcrop/duke_energy/Phaseolus_vulgaris.html (accessed on 15 July 2017).

37. Caporaso, J.G.; Lauber, C.L.; Walters, W.A.; Berg-Lyons, D.; Huntley, J.; Fierer, N.; Owens, S.M.; Betley, J.; Fraser, L.; Bauer, M.; et al. Ultra-high-throughput microbial community analysis on the Illumina HiSeq and MiSeq platforms. ISME J. 2012, 6, 1621-1624. [CrossRef]

38. Caporaso, J.G.; Kuczynski, J.; Stombaugh, J.; Bittinger, K.; Bushman, F.D.; Costello, E.K.; Fierer, N.; Peña, A.G.; Goodrich, J.K.; Gordon, J.I.; et al. QIIME allows analysis of high-throughput community sequencing data. Nat. Methods 2010, 7, 335-336. [CrossRef] [PubMed]

39. Laubitz, D.; Harrison, C.A.; Midura-Kiela, M.T.; Ramalingam, R.; Larmonier, C.B.; Chase, J.H.; Caporaso, J.G.; Besselsen, D.G.; Ghishan, F.K.; Kiela, P.R. Reduced epithelial Na+/H+ exchange drives gut microbial dysbiosis and promotes inflammatory response in T cell-mediated murine colitis. PLoS ONE 2016, 11, e0152044. [CrossRef]

40. Edgar, R.C. Search and clustering orders of magnitude faster than BLAST. Bioinformatics 2010, 26, $2460-2461$. [CrossRef]

41. Caporaso, J.G.; Bittinger, K.; Bushman, F.D.; DeSantis, T.Z.; Andersen, G.L.; Knight, R. PyNAST: A flexible tool for aligning sequences to a template alignment. Bioinformatics 2010, 26, 266-267. [CrossRef] [PubMed]

42. DeSantis, T.Z.; Hugenholtz, P.; Larsen, N.; Rojas, M.; Brodie, E.L.; Keller, K.; Huber, T.; Dalevi, D.; Hu, P.; Andersen, G.L. Greengenes, a chimera-checked $16 \mathrm{~S}$ rRNA gene database and workbench compatible with ARB. Appl. Environ. Microbiol. 2006, 72, 5069-5072. [CrossRef]

43. Haas, B.J.; Gevers, D.; Earl, A.M.; Feldgarden, M.; Ward, D.V.; Giannoukos, G.; Ciulla, D.; Tabbaa, D.; Highlander, S.K.; Sodergren, E.; et al. Chimeric 16S rRNA sequence formation and detection in Sanger and 454-pyrosequenced PCR amplicons. Genome Res. 2011, 21, 494-504. [CrossRef]

44. Wang, Q.; Garrity, G.M.; Tiedje, J.M.; Cole, J.R. Naive Bayesian classifier for rapid assignment of rRNA sequences into the new bacterial taxonomy. Appl. Environ. Microbiol. 2007, 73, 5261-5267. [CrossRef] [PubMed]

45. Price, M.N.; Dehal, P.S.; Arkin, A.P. FastTree 2-Approximately maximum-likelihood trees for large alignments. PLoS ONE 2010, 5, e9490. [CrossRef] [PubMed] 
46. Lozupone, C.; Knight, R. UniFrac: A new phylogenetic method for comparing microbial communities. Appl. Environ. Microbiol. 2005, 71, 8228-8235. [CrossRef]

47. R Core Team. R: A Language and Environment for Statistical Computing; R Foundation for Statistical Computing: Vienna, Austria, 2014; Available online: https://www.R-project.org/ (accessed on 21 May 2020).

48. McMurdie, P.J.; Holmes, S. Phyloseq: An R package for reproducible interactive analysis and graphics of microbiome census data. PLoS ONE 2013, 8, e61217. [CrossRef]

49. Louca, S.; Parfrey, L.W.; Doebeli, M. Decoupling function and taxonomy in the global ocean microbiome. Science 2016, 353, 1272-1277. [CrossRef]

50. Warenes, G.R.; Bolker, B.; Bonebakker, L.; Gentleman, R.; Huber, W.; Liaw, A.; Lumley, T.; Maechler, M.; Magnusson, A.; Moeller, S.; et al. gplots: Various R Programming Tools for Plotting Data; R Package Version; 2016. Available online: https://rdrr.io/cran/gplots/ (accessed on 21 May 2020).

51. Oksanen, J. Multivariate Analysis of Ecological Communities in R: Vegan tutorial; 2015; pp. 1-40. Available online: https://www.mooreecology.com/uploads/2/4/2/1/24213970/vegantutor.pdf (accessed on 21 May 2020).

52. Dray, S.; Dufor, A.-B.; Thioulouse, J. Analysis of Ecological Data: Exploratory and Euclidean Methods in Environmental Sciences. 2018. Available online: https://rdrr.io/cran/ade4/ (accessed on 21 May 2020).

53. Tilman, D.; Cassman, K.G.; Matson, P.A.; Naylor, R.; Polasky, S. Agricultural sustainability and intensive production practices. Nature 2002, 418,671-677. [CrossRef]

54. Solís-Domínguez, F.A.; Valentín-Vargas, A.; Chorover, J.; Maier, R.M. Effect of arbuscular mycorrhizal fungi on plant biomass and the rhizosphere microbial community structure of mesquite grown in acidic lead/zinc mine tailings. Sci. Total Environ. 2011, 409, 1009-1016. [CrossRef]

55. Martinez-Romero, E.; Segovia, L.; Mercante, F.M.; Franco, A.A.; Graham, P.; Pardo, M.A. Rhizobium tropici, a novel species nodulating phaseolus vulgaris 1 . beans and leucaena sp. trees. Int. J. Syst. Bacteriol. 1991, 41, 417-426. [CrossRef] [PubMed]

56. Martínez-Romero, E. Diversity of rhizobium-phaseolus vulgaris symbiosis: Overview and perspectives. Plant Soil 2003, 252, 11-23. [CrossRef]

57. Gtari, M.; Ghodhbane-Gtari, F.; Nouioui, I.; Beauchemin, N.; Tisa, L.S. Phylogenetic perspectives of nitrogen-fixing actinobacteria. Arch. Microbiol. 2012, 194, 3-11. [CrossRef]

58. Neilson, J.W.; Quade, J.; Ortiz, M.; Nelson, W.M.; Legatzki, A.; Tian, F.; LaComb, M.; Betancourt, J.L.; Wing, R.A.; Soderlund, C.A.; et al. Life at the hyperarid margin: Novel bacterial diversity in arid soils of the Atacama Desert, Chile. Extremophiles 2012, 16, 553-566. [CrossRef]

59. Kardol, P.; De Deyn, G.B.; Laliberté, E.; Mariotte, P.; Hawkes, C.V. Biotic plant-soil feedbacks across temporal scales. J. Ecol. 2013, 101, 309-315. [CrossRef]

60. Kelly, L.C.; Cockell, C.S.; Herrera-Belaroussi, A.; Piceno, Y.; Andersen, G.; DeSantis, T.; Brodie, E.; Thorsteinsson, T.; Marteinsson, V.; Poly, F.; et al. Bacterial diversity of terrestrial crystalline volcanic rocks, Iceland. Microb. Ecol. 2011, 62, 69-79. [CrossRef]

61. Akob, D.M.; Küsel, K. Where microorganisms meet rocks in the Earth's Critical Zone. Biogeosciences 2011, 8, 3531-3543. [CrossRef]

62. Knelman, J.E.; Legg, T.M.; O’Neill, S.P.; Ashenberger, C.L.W.; Gonzalez, A.G.; Cleveland, C.C.; Nemergut, D.R. Bacterial community structure and function change in association with colonizer plants during early primary succession in a glacier forefield. Soil Biol. Biochem. 2012, 46, 172-180. [CrossRef]

(C) 2020 by the authors. Licensee MDPI, Basel, Switzerland. This article is an open access article distributed under the terms and conditions of the Creative Commons Attribution (CC BY) license (http://creativecommons.org/licenses/by/4.0/). 